\title{
INFLUENCE OF LAND-COVER CHANGE ON THE SPREAD OF AN INVASIVE FOREST PATHOGEN
}

\author{
Ross K. Meentemeyer, ${ }^{1,4}$ Nathan E. Rank, ${ }^{2}$ Brian L. Anacker, ${ }^{1,5}$ David M. Rizzo, ${ }^{3}$ and J. Hall Cushman ${ }^{2}$ \\ ${ }^{1}$ Department of Geography and Earth Sciences, University of North Carolina at Charlotte, Charlotte, North Carolina 28223 USA \\ ${ }^{2}$ Department of Biology, Sonoma State University, Rohnert Park, California 94928 USA \\ ${ }^{3}$ Department of Plant Pathology, University of California, Davis, California 95616 USA
}

\begin{abstract}
Human-caused changes in land use and land cover have dramatically altered ecosystems worldwide and may facilitate the spread of infectious diseases. To address this issue, we examined the influence of land-cover changes between 1942 and 2000 on the establishment of an invasive pathogen, Phytophthora ramorum, which causes the forest disease known as Sudden Oak Death. We assessed effects of land-cover change, forest structure, and understory microclimate on measures of inoculum load and disease prevalence in $10215 \times 15$ $\mathrm{m}$ plots within a $275-\mathrm{km}^{2}$ region in northern California. Within a $150 \mathrm{~m}$ radius area around each plot, we mapped types of land cover (oak woodland, chaparral, grassland, vineyard, and development) in 1942 and 2000 using detailed aerial photos. During this 58-year period, oak woodlands significantly increased in area by $25 \%$, while grassland and chaparral decreased by $34 \%$ and 51\%, respectively. Analysis of covariance revealed that vegetation type in 1942 and woodland expansion were significant predictors of pathogen inoculum load in bay laurel (Umbellularia californica), the primary inoculum-producing host for P. ramorum in mixed evergreen forests. Path analysis showed that woodland expansion resulted in larger forests with higher densities of the primary host trees (U. californica, Quercus agrifolia, Q. kelloggii) and cooler understory temperatures. Together, the positive effects of woodland size and negative effects of understory temperature explained significant variation in inoculum load and disease prevalence in bay laurel; host stem density had additional positive effects on inoculum load. We conclude that enlargement of woodlands and closure of canopy gaps, likely due largely to years of fire suppression, facilitated establishment of $P$. ramorum by increasing the area occupied by inoculum-production foliar hosts and enhancing forest microclimate conditions. Epidemiological studies that incorporate land-use change are rare but may increase understanding of disease dynamics and improve our ability to manage invasive forest pathogens.
\end{abstract}

Key words: fire suppression; forest microclimate; landscape epidemiology; path analysis; Phytophthora ramorum; simultaneous autoregressive (SAR) modeling; Sudden Oak Death.

\section{INTRODUCTION}

Human land-use practices have dramatically altered the land cover of natural environments worldwide, resulting in reductions in biodiversity (Turner et al. 1998, Dupouey et al. 2002), decreases in air and water quality (Wear et al. 1998), and alterations to ecosystem processes (Foster et al. 2003, Turner et al. 2003). Another potential consequence of land-cover change is the creation of environmental conditions that promote infectious disease (Foley et al. 2005). Agriculture, timber harvesting, road building, and human-caused species introduction each may enhance the emergence and spread of infectious disease by creating new transmission pathways and changing ecosystem structure (Patz et al.

Manuscript received 9 February 2007; revised 2 July 2007; accepted 27 July 2007. Corresponding Editor: S. M. Altizer.

${ }^{4}$ E-mail: rkmeente@uncc.edu

${ }^{5}$ Present address: Department of Environmental Science and Policy, University of California, Davis, California 95616 USA.
2000, Holdenreider et al. 2004). For example, tropical deforestation has caused an upsurge of malaria by increasing the amount of habitat suitable for mosquito larval vectors (Coluzzi 1994, Vitor et al. 2006). In addition, forest fragmentation has been linked with elevated Lyme disease risk, with smaller forest patches supporting increased densities of infected nymphal ticks (Allan et al. 2003).

Over the past decade, Sudden Oak Death has reached epidemic levels in coastal forests of northern California and southwestern Oregon, killing large numbers of oak (Quercus sp.) and tanoak (Lithocarpus densiflorus) trees and infecting a wide range of other host plant species (Rizzo et al. 2002, 2005). This disease is caused by Phytophthora ramorum, a generalist water mold pathogen that infects over 40 plant genera and causes symptoms that are expressed in two distinct forms: nonlethal foliar and twig infections that can produce large numbers of dispersal spores, and canker infections that do not lead to production of spores but can cause tree mortality (Rizzo and Garbelotto 2003; see Plate 1). 
Thus, transmission of the disease is driven primarily by infection among foliar host species; in contrast, Quercus species, strictly a canker host, do not contribute to spread of the pathogen (Garbelotto et al. 2003, Davidson et al. 2005, Rizzo et al. 2005). California bay laurel (Umbellularia californica) is considered to be an especially important foliar host of Sudden Oak Death because it produces large amounts of inoculum (Davidson et al. 2005) and is associated with mortality of oak (Kelly and Meentemeyer 2002, Swiecki and Bernhardt 2006) and tanoak (Maloney et al. 2005). Therefore, both the abundance and type of foliar host species present are important determinants of a forest's susceptibility to invasion by P. ramorum (Meentemeyer et al. 2004, Rizzo et al. 2005).

Post-European land uses have substantially altered the structure and composition of forest communities in California (Barbour et al. 1993, Keeley 2002a) in ways that might increase transmission of $P$. ramorum. These modifications include fire suppression, human-ignited fires, logging, grazing, and introduced plant and animal species. For the last 100 years, forest fires in California and the western United States more generally have been actively suppressed to protect human property and wildlife (Sugihara et al. 2006). This reduction in fire frequency may be causing critical changes to forest structure, including increases in the density of small, young trees, decreases in tree canopy gaps, and expansions in the perimeter of woodlands (Moritz and Odion 2005). Many areas that are currently dominated by forests may have been different types of vegetation only decades ago. For example, McBride (1974) and Safford (1995) both found that some forests are undergoing shifts over time from oak-dominated toward bay laurel-dominated communities. In other areas, past logging practices have shifted forest composition to tanoak and bay laurel due to loss of coast redwood and Douglas-fir (Barbour et al. 1993). Changes in the area, density and host composition of woodlands may be especially important types of forest change for $P$. ramorum because greater amounts of pathogen inoculum have been shown to occur in forests with high landscape connectivity and high abundance of foliar host vegetation (Condeso and Meentemeyer 2007). Thus, by the time $P$. ramorum was introduced into California, decades of land-use change and associated increases in host abundance may have set the stage for this pathogen's rapid rate of spread. On the other hand, human land-use practices have also resulted in loss of woodland habitat due to development and vineyard establishment (Merenlender 2000), which could slow the spread of $P$. ramorum across a landscape. While our understanding of the biology of $P$. ramorum and its mechanisms for dispersal have increased greatly (Davidson et al. 2002, 2005, Rizzo et al. 2002, 2005), no studies have examined the potential influence of humandriven land-cover change on disease establishment.
We hypothesize that oak woodlands in rural regions of coastal California have increased in density and expanded into grasslands and shrublands in recent decades, leading to host and microclimate conditions suitable for P. ramorum. Based on the hypothesis that historic land-use change created current conditions favoring disease, we expect to see greater density of infected trees in landscapes that have experienced increases in woodland cover and connectivity over the past century. To test this prediction, we examined three questions: (1) Has host vegetation for P. ramorum increased in area between 1942 and 2000? (2) Is $P$. ramorum inoculum load and disease prevalence related to patterns of land-cover change? (3) Has land-cover change affected forest structure and understory microclimate in ways that enhance severity of infection by $P$. ramorum? To assess disease level, we quantified density of bay laurel stems and leaves showing symptoms of $P$. ramorum. We focused on this very abundant foliar host because it is the main producer of $P$. ramorum inoculum in mixed evergreen forests and frequently co-occurs with susceptible oak species (Rizzo et al. 2005; see Plate 1). Understanding the influence of land-cover change on disease dynamics is critical for minimizing further spread of Sudden Oak Death and other emerging infectious diseases.

\section{Methods \\ Study site and plot distribution}

Our study was conducted within a $275-\mathrm{km}^{2}$ heterogeneous region $70 \mathrm{~km}$ north of San Francisco, California (Fig. 1). This region was selected because it contains a mosaic of vegetation and land-cover types, including oak woodland, redwood-tanoak forest, chaparral shrubland, annual grassland, agricultural areas, and scattered residential developments. The geographic extent of our study area was designed to capture landscape-scale variability in environmental conditions and disease spread. Phytophthora ramorum was first observed within our study area in 2000 , and is now distributed throughout most of the suitable habitat in this region.

To identify suitable locations for study sites, we mapped all oak woodland areas using geo-rectified multi-spectral aircraft imagery (ADAR, Positive Systems, Whitefish, Montana, USA). The imagery was collected in July 2001 as four spectral bands of data (red, green, blue, and near infrared) at a spatial resolution of $1 \times 1 \mathrm{~m}$ pixels, and classified as either oak or non-oak woodland using unsupervised ISODATA image processing (Erdas Imagine 8.7, Leica Geosystems, Norcross, Georgia, USA). Using a GIS, we established 102 randomly located $15 \times 15 \mathrm{~m}$ field plots in areas mapped as oak woodland on public ( $n=57$ plots) and private $(n$ $=45$ plots) lands (Fig. 1). Plot locations were spaced at least $300 \mathrm{~m}$ apart to avoid sampling at the spatial scale within which oak infection is known to be clustered (Kelly and Meentemeyer 2002). The location of each 


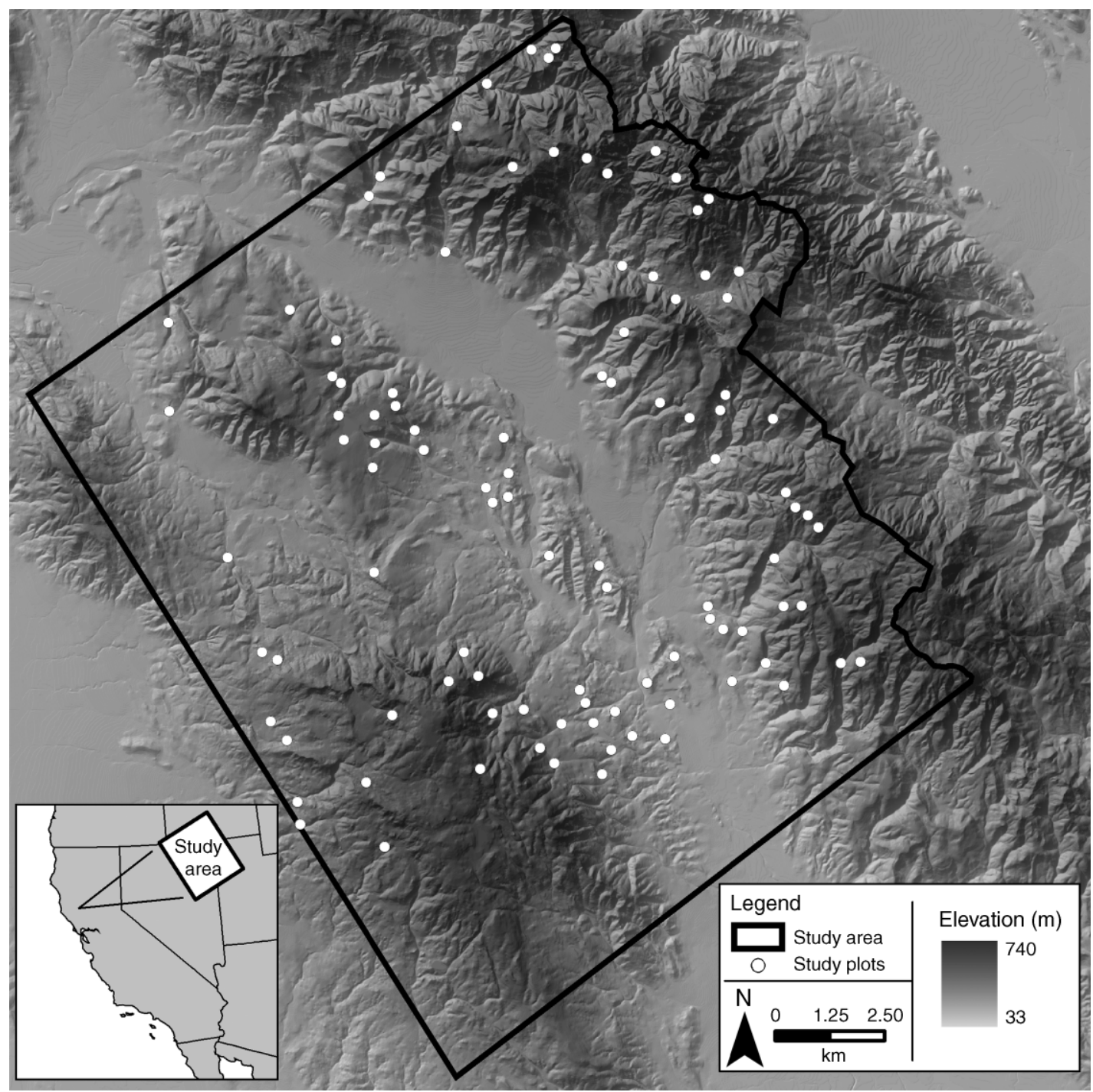

FIG. 1. Locations of 102 field plots randomly located within oak woodland habitat where historic aerial photographs were available in a $275-\mathrm{km}^{2}$ study area in eastern Sonoma County, California, USA. Solid circles are scaled to represent the size of the $150 \mathrm{~m}$ radius landscape areas surrounding each $15 \times 15 \mathrm{~m}$ field plot.

plot was confirmed in the field using survey-grade global positioning system receivers with a horizontal accuracy of $1 \mathrm{~m}$ or less after differential correction (Trimble Navigation Limited, Sunnyvale, California, USA).

\section{Land-cover changes}

For each $15 \times 15 \mathrm{~m}$ woodland plot, we photointerpreted its land-cover type from archived aerial photographs from 1942, the earliest year that reliable, high-quality imagery was available. We also analyzed land-cover changes in a $150 \mathrm{~m}$ radius circular area $(7.1$ ha) surrounding each plot by comparing digital panchromatic imagery from 2000 to the archived air photos taken in 1942 (Fig. 2). We selected a $150 \mathrm{~m}$ radius area to measure land-cover change because previous research had shown that spatial pattern of host vegetation most strongly predicted $P$. ramorum disease level at this scale (Condeso and Meentemeyer 2007). This radius distance was also chosen to prevent sampling overlap between adjacent plots. The 2000 imagery was digitally orthorectified and produced at a spatial resolution of $0.6-\mathrm{m}$ pixels. We scanned archived 1942 photos (1:8000) at 600 dpi and geo-referenced them in a GIS to match the coordinate system and spatial resolution of the 2000 imagery (0.6-m pixels), and we used a minimum mapping unit of $9 \mathrm{~m}^{2}$ to capture fine-scale changes in land cover. Within each $150 \mathrm{~m}$ radius area, we used GIS to manually trace boundaries of five common land-cover types: oak woodland, chaparral shrubland, grassland, agriculture, and development (Fig. 2). We defined development as buildings, roads, parking lots, manmade ponds, and lawns. Agricultural areas consisted of 


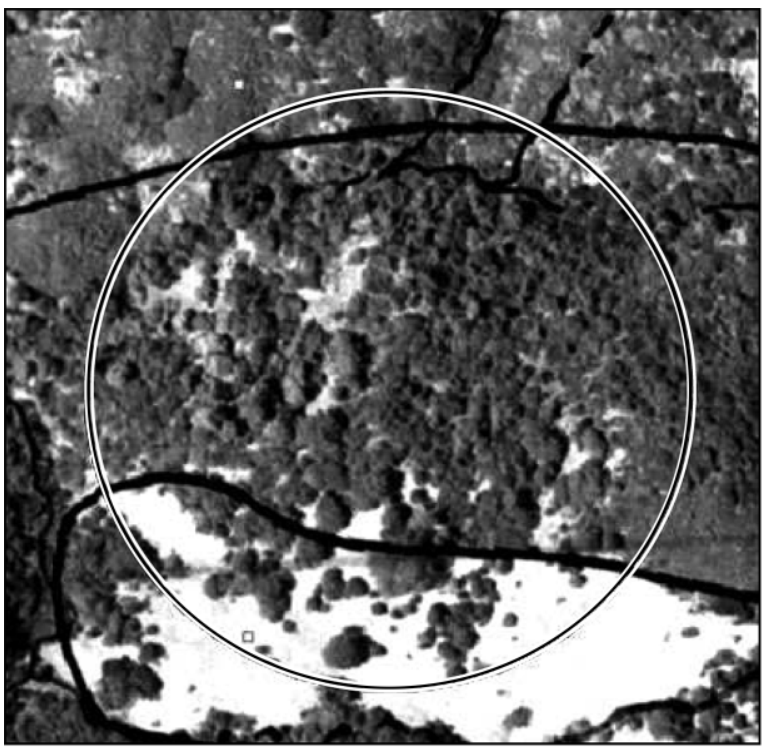

1942

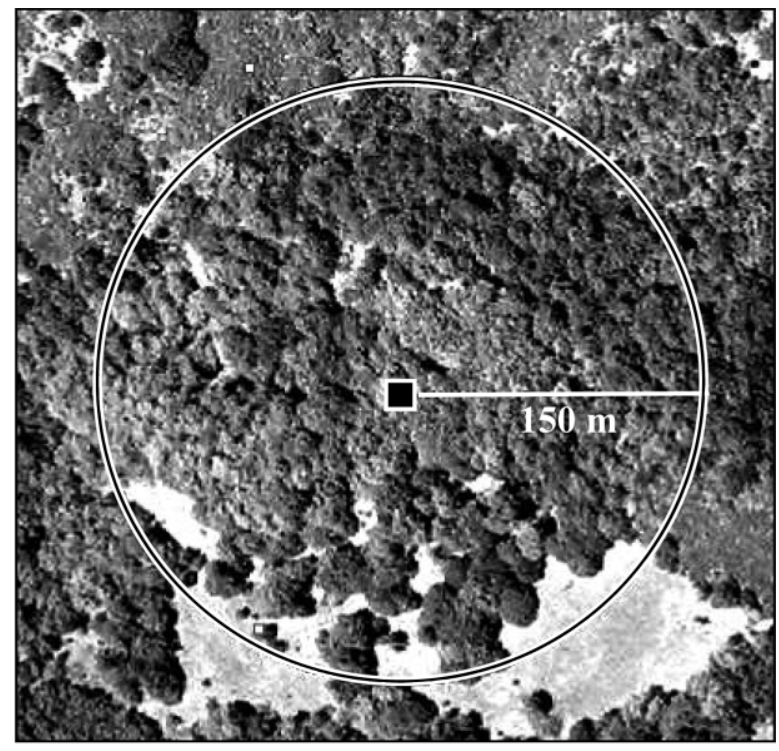

2000

FIG. 2. Example of aerial photography used to map changes in land cover between 1942 and 2000. Five land-cover types were mapped within a $150 \mathrm{~m}$ radius study area (7.1 ha): oak woodland, chaparral shrubland, grassland, agriculture, and development. Vegetation sampling was conducted in a $15 \times 15 \mathrm{~m}$ plot $\left(225 \mathrm{~m}^{2}\right)$ at the center of each area. Considerable woodland expansion and canopy closure occurred between 1942 and 2000 in this example.

vineyards and orchards. We used Fragstats 3.3 (McGarigal et al. 2002) to calculate patch number, patch size, and total area of each land-cover type for 1942 and 2000 .

\section{Inoculum load and disease prevalence}

Within each $15 \times 15 \mathrm{~m}$ study plot, we measured the diameter at breast height (dbh) of the three most abundant host trees of $P$. ramorum: coast live oak, black oak, and bay laurel. We measured all stems that exceeded $5 \mathrm{~cm}$ in dbh and $1.4 \mathrm{~m}$ in height and counted the number of symptomatic leaves for 90 seconds on each stem of the key inoculum producing host bay laurel (see Condeso and Meentemeyer 2007) during peak expression of symptoms between 15 April and 15 May in 2005 and 2006 (see Plate 1). From these data, we derived two metrics of inoculum load (total number of symptomatic leaves and density of symptomatic stems) and one metric of disease prevalence (proportion of symptomatic stems) for each of our 102 plots. The inoculum load variables provide information on the abundance of $P$. ramorum in a plot, reflecting the degree to which a plot can serve as a source for future infections, while the prevalence variable examines risk of infection for individual bay laurel plants at a given site. Coast live oak and black oak were also assessed for $P$. ramorum symptoms of "bleeding" lesions (dark red exudates and discoloration of bark surface) and large numbers of dead leaves in the crown (Davidson et al. 2003).

We tested for the presence of $P$. ramorum in every plot by collecting 15 symptomatic leaves from three to five randomly selected bay laurel individuals per plot and baiting the pathogen using standard culturing techniques (Davidson et al. 2003). The pathogen was cultured from $97 \%$ of the symptomatic trees sampled and $92 \%$ of the symptomatic leaves sampled. No other Phytophthora species that cause similar leaf symptoms were detected in the study region.

\section{Abiotic variables}

At the center of each plot, we measured understory temperature and relative humidity at hourly intervals between 1 May 2004 and 30 April 2006. The microclimate data loggers were mounted on a pole $1 \mathrm{~m}$ above ground level and housed in a protective solar shield (Onset Corporation, Bourne, Massachusetts, USA). These dates span two dry and two rainy seasons in our study region's Mediterranean climate and encompass the period over which P. ramorum infection status was assessed. We calculated averages of daily minimum, mean, and maximum temperature and relative humidity over each dry (1 May-30 October) and rainy season (1 November-30 April) after careful examination of each logger's data to eliminate erroneous values.

We also used a GIS to derive two topographic variables for each plot using a USGS 10-m digital elevation model; average potential direct solar insolation (SII) during the rainy season (Dubayah 1994), and the topographic moisture index (TMI), which characterized effects of local topography on soil moisture as the natural $\log$ of the ratio between upslope drainage area and the slope gradient of a given grid cell (Moore et al. 1991). 
TABLE 1. Characteristics of bay laurel (Umbellularia californica), coast live oak (Quercus agrifolia), and black oak (Q. kelloggii), the three main tree hosts of Phytophthora ramorum, in eastern Sonoma County, California, USA.

\begin{tabular}{|c|c|c|c|c|c|c|}
\hline \multirow[b]{3}{*}{ Variable } & \multicolumn{6}{|c|}{ Host species } \\
\hline & \multicolumn{2}{|c|}{ Bay laurel } & \multicolumn{2}{|c|}{ Coast live oak } & \multicolumn{2}{|c|}{ Black oak } \\
\hline & $\bar{x}$ & SD & $\bar{x}$ & SD & $\bar{x}$ & SD \\
\hline \multicolumn{7}{|l|}{ a) All plots $(n=102)$} \\
\hline Stem density $\dagger$ & 13.2 & 16.0 & 3.2 & 4.4 & 1.5 & 3.1 \\
\hline Cumulative dbh & 153.2 & 163.8 & 83.1 & 112.5 & 36.2 & 67.8 \\
\hline Proportion of plots with disease & 0.90 & 0.31 & 0.16 & 0.37 & 0.17 & 0.38 \\
\hline \multicolumn{7}{|l|}{ b) Plots with tree species } \\
\hline Stem density $\dagger$ & 15.5 & $11.4 t$ & 5.08 & $4.56 \S$ & 4.23 & $4.15^{\bullet}$ \\
\hline Mean dbh & 13.4 & $11.1 \%$ & 29.6 & $21.1 \S$ & 29.7 & 11.8 \\
\hline Symptomatic stem density & 11.4 & $12.9 \ddagger$ & 0.23 & $0.58 \S$ & 0.20 & 0.42 \\
\hline Number of symptomatic leaves & 58.4 & $48.1 t$ & & & & \\
\hline Prevalence (proportion of stems symptomatic) & 0.71 & $0.31 \ddagger$ & 0.06 & $0.20 \S$ & 0.12 & 0.29 \\
\hline
\end{tabular}

Notes: The top panel (a) presents mean values for each species over the entire sample of plots; panel (b) presents mean values in plots where each species was present. Leaf lesions of P. ramorum occur only on bay laurel.

$\dagger$ Number of trees per $225 \mathrm{~m}^{2}(15 \times 15 \mathrm{~m})$ field plot.

$\$$ Based on $n=87$ plots.

$\S$ Based on $n=63$ plots.

$\uparrow$ Based on $n=36$ plots.

\section{Statistical analyses}

To analyze land-cover changes, we calculated the difference of each land-cover type's total area, mean patch size, and number of patches between 1942 and 2000 (sum of $t_{2000}-$ sum of $t_{1942}$ ). We analyzed the magnitude of changes using nonparametric two-tailed Wilcoxon signed-ranks tests, evaluating the null hypothesis that there was no difference in area, mean patch size, and patch number among years. We adjusted the significance level of probabilities by the number of tests (five) made using the sequential Bonferroni method (Rice 1989). All statistical analyses were performed using JMP 6.02 (SAS Institute, Cary, North Carolina).

To assess whether woodland expansion is related to $P$. ramorum inoculum load and disease prevalence in 2005 2006, we conducted three analyses of covariance (ANCOVAs), with woodland area change as the covariate, plot vegetation type in 1942 as the grouping factor, and density of symptomatic bay laurel stems, number of symptomatic leaves, and proportion of symptomatic stems as response variables. To assure assumptions of multiple regression were not violated, we log transformed values for mean density of symptomatic stems and number of symptomatic leaves and squareroot transformed values for the difference in land cover between 1942 and 2000 (after adding the minimum difference to all values to avoid square roots of negative numbers). We did not test for a relationship between land-cover change and oak infection due to the current low prevalence of infection among these canker hosts at our sites (Table 1). This study area is in an earlier stage of invasion by $P$. ramorum than more southern regions such as Marin County and Big Sur (Rizzo et al. 2005).

We used path analysis (sensu Schemske and Horvitz 1988) to quantify direct and indirect effects of landcover change, topographic position, woodland area, forest structure, and understory microclimate on inoculum load (number of symptomatic leaves and density of symptomatic stems) and prevalence of $P$. ramorum in bay laurel. Path analysis has been shown to be an effective method for examining hypothesized causeeffect relationships in historical, multi-scale ecological studies (Shipley 1997, Grace and Pugesek 1998). We constructed pathways based on the following hypotheses (Fig. 3): (1) woodland expansion leads to increased densities of host and non-host trees; (2) greater tree density creates cooler, moister forest microclimate conditions most suitable for production and transmission of the pathogen; (3) higher density of host individuals directly contributes to greater levels of inoculum production and increases connectivity of host vegetation; and (4) topographic variables such as solar insolation and surface moisture should influence pathogen inoculum load and disease prevalence indirectly through their direct effects on forest microclimate, woodland patch size, and forest structure. This analytical technique was well suited for our research questions because the historical data allowed us to position landcover change at the foundation of the hypothesized path structure.

To estimate the path coefficients for the effect of each predictor variable on pathogen inoculum load and disease prevalence, we first standardized all variables by subtracting the grand mean of each variable and dividing by the grand standard deviation of each variable (Schemske and Horvitz 1988). Standardization allows the strength of linear relationships to be compared because estimates of path coefficients do not depend on the magnitude of original values. To examine if our hypothesized paths were supported by these data, we performed multiple regression analyses for the following response variables: (1) pathogen inoculum load (number 


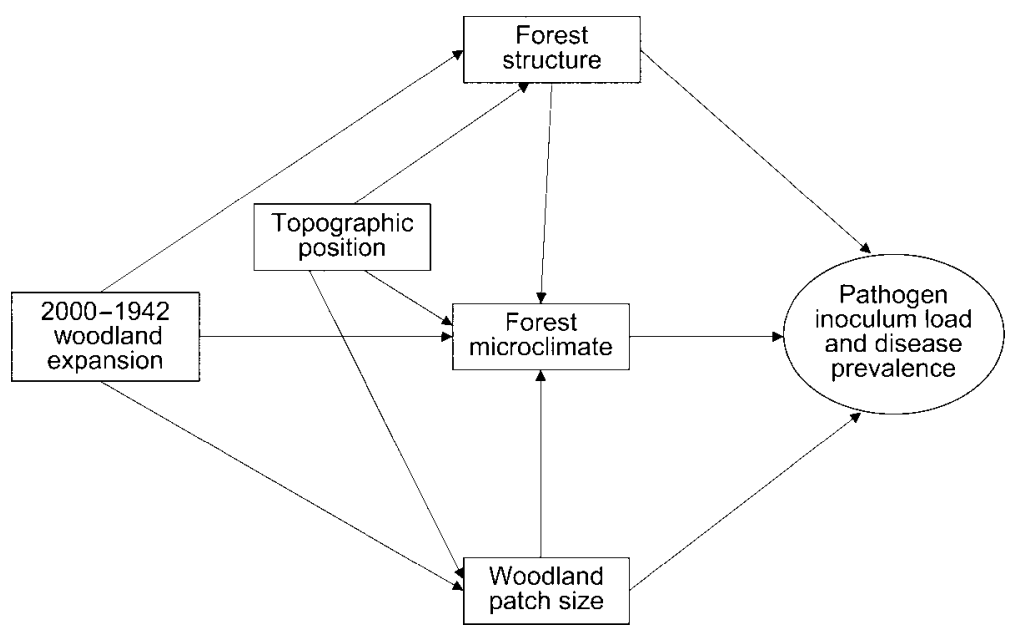

FIG. 3. Hypothesized pathways describing how land-cover change has affected forest structure and understory microclimate in ways that facilitate severity of infection by Phytophthora ramorum, an invasive watermold pathogen.

of symptomatic leaves, density of symptomatic stems) and disease prevalence (proportion of symptomatic stems), (2) understory microclimate, (3) woodland area in 2000 , and (4) current forest structure. We used the following predictor variables in these regressions: topography (SII, TMI), woodland change (transformed difference in area between 1942 and 2000), woodland area in 2000 , forest structure (total stem density and cumulative dbh of bay laurel, coast live oak and black oak), and understory microclimate (minimum and maximum daily temperature, minimum daily relative humidity). Spatial autocorrelation in geographically structured data sets can compromise assumptions of statistical independence in ecological models (Legendre et al. 2002, Diniz-Filho et al. 2003). To account for potential spatial autocorrelation in each path analysis model, we used simultaneous autoregressive (SAR) modeling, a regression technique designed to adjust the strength and significance of spatially correlated variables (Cressie 1993, Lichstein et al. 2002). SAR analyses were performed using Spatial Analysis in Macroecology software (SAM; see Rangel et al. 2006; software available online) ${ }^{6}$

We ran preliminary regressions and selected the model with the lowest value for the Akaike Information Coefficient (AIC) to determine which of our candidate variables from each category to include in the final path analyses. These regressions revealed that models with host stem density (oak species and bay laurel) and maximum daily temperature showed lower AIC values than other forest structure or microclimate variables in predicting pathogen inoculum load and disease prevalence. Thus, we selected host stem density and maximum daily temperature for inclusion in the path analysis. Other regressions revealed that models with solar insolation showed lower AIC values than those with

\footnotetext{
${ }^{6}\langle$ www.ecoevol.ufg.br/sam $/\rangle$
}

topographic moisture index in predicting forest structure, microclimate, and woodland patch size in 2000. Thus, we selected solar insolation as the topographic variable in the path analysis.

\section{RESULTS \\ Land-cover changes}

Within our 102 randomly located study sites, woodland area increased by $25 \%$ over the 58 -year period, while grassland and chaparral decreased in area $(34.1 \%$ and $51.7 \%$, respectively; Fig. 4). Increases in woodland expansion were most strongly correlated with loss of chaparral shrubland (Pearson correlation coefficient $r=$ $-0.81, P<0.0001)$. The mean size of woodland patches increased by $50.1 \%\left(F_{1,101}=42.9, P<0.0001\right)$, while number of woodland patches decreased by $14.5 \%\left(F_{1,101}\right.$ $=25.8, P<0.0001)$. Only $16 \%$ of the 102 sites did not experience woodland expansion. Developed land increased twofold (1\% to 2.3\%), and area of agriculture remained stable (Fig. 4).

\section{Land-cover change and disease spread}

Bay laurel was the most abundant host tree and it expressed symptoms of $P$. ramorum infection much more often than oak species (Wilcoxon signed-ranks test, $\mathrm{df}=$ 67, $P<0.0001$; Table 1). Plots contained a higher density of small bay laurel stems than oak species (Wilcoxon signed-ranks test, $\mathrm{df}=102, P<0.0001$ ), but cumulative dbh of bay laurel did not differ significantly from oak species (Wilcoxon signed-ranks test, $\mathrm{df}=101$, $P=0.28$; Table 1a). Symptomatic bay laurel stem density and number of symptomatic bay laurel leaves were positively related to increases in woodland area. These measures of disease expression were also lower in plots that were grassland in 1942 (Fig. 5). The proportion of symptomatic stems variable was positively related to woodland area change $\left(F_{1,83}=1.48 ; P=0.23\right)$ 


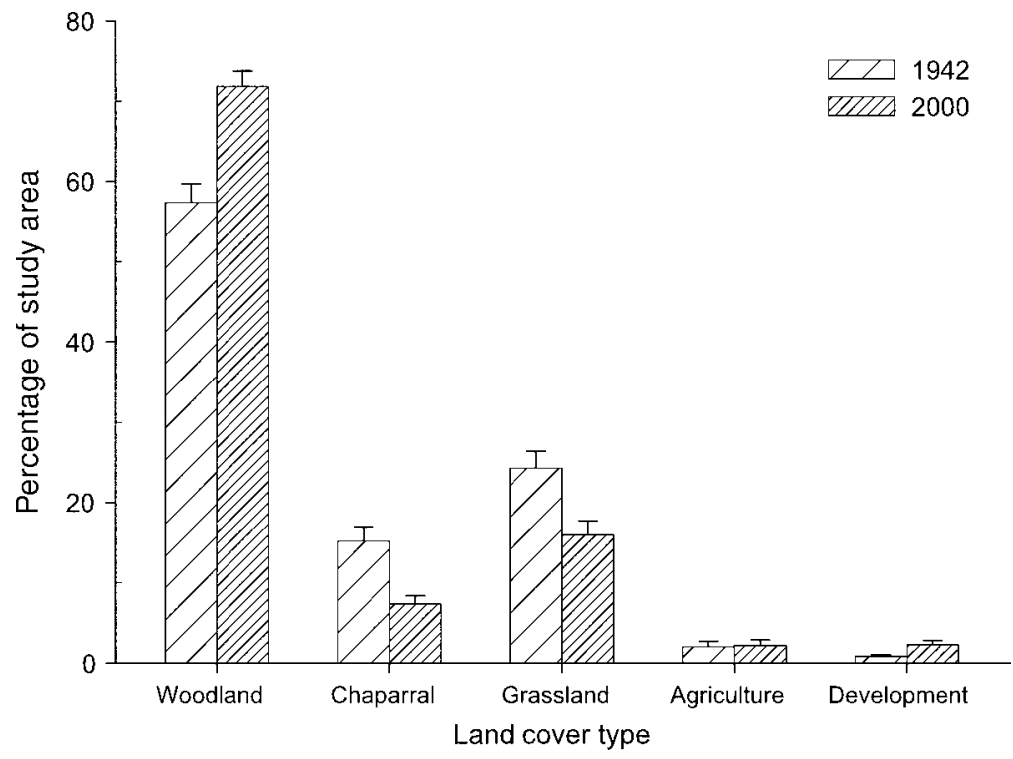

FIG. 4. Changes in area of each land-cover type between 1942 and 2000 ( $n=102$ plots). Values are expressed as the percentage of each 7.1-ha area (mean + SE). Changes in woodland, chaparral, and grassland were highly significant $(P<0.0001$, Wilcoxon signed-ranks tests). The sequential Bonferroni method was used to adjust probabilities for multiple statistical tests.
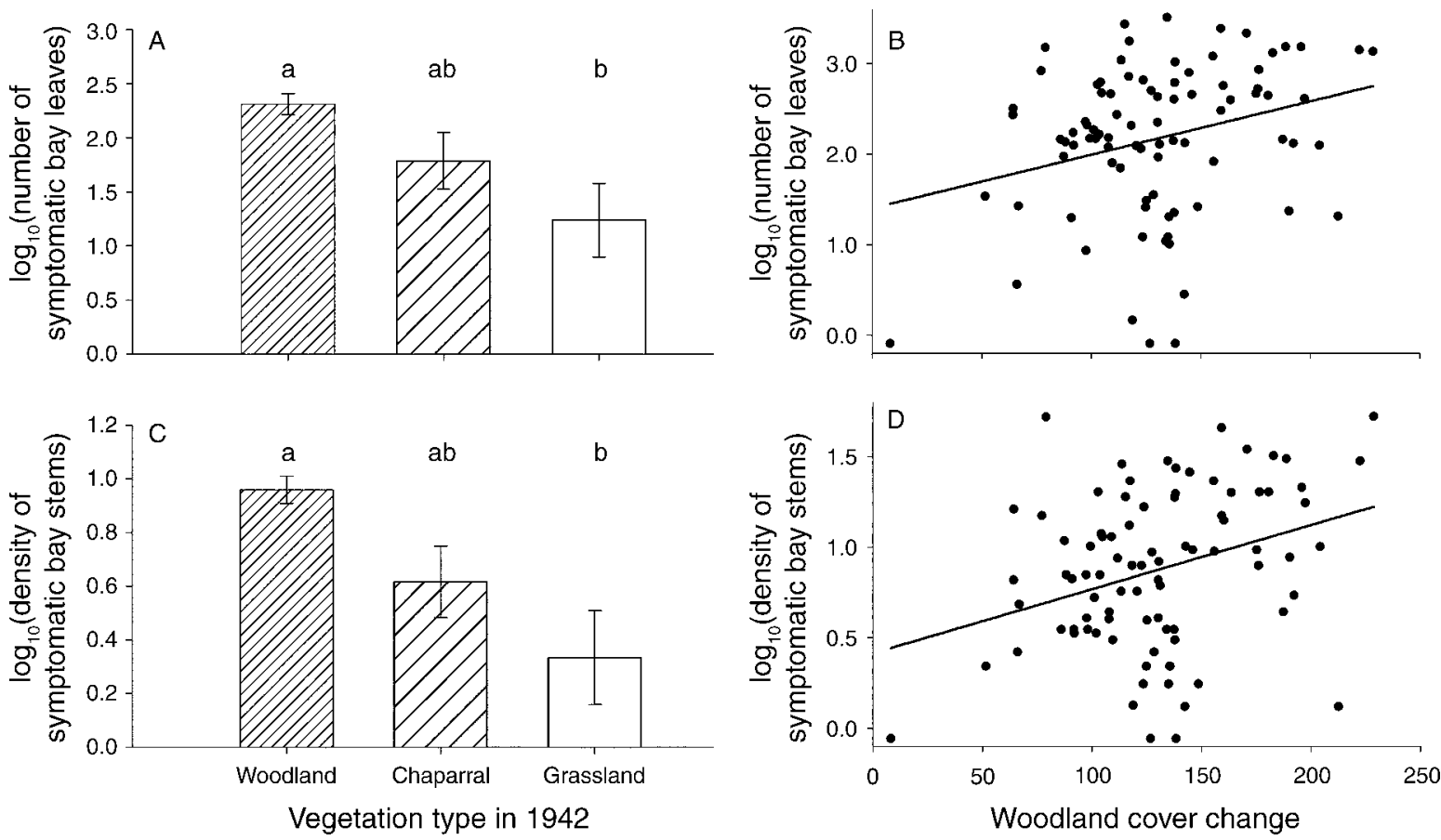

FIG. 5. Relationship between land-cover change and vegetation type of the $225-\mathrm{m}^{2}$ plots in 1942 and Phytophthora ramorum inoculum load on bay laurel (Umbellularia californica) in 2005-2006 ( $n=87$ plots). (A, C) Least-square means and standard errors for log-transformed symptomatic leaf and stem density data from ANCOVA (for panel A, $F_{3,83}=9.8, P<0.0012$; for panel C, $F_{3,83}$ $=7.2, P=0.0066)$. Letters indicate significantly different $(P<0.05)$ means based on Tukey's hsd test. $(\mathrm{B}, \mathrm{D})$ Leverage plots from ANCOVA model showing the relationship between land-cover change and symptomatic leaf number and symptomatic stem density in the 7.1-ha study area. Woodland cover change was measured as (cover in 2000) - (cover in 1942) and was square-root transformed. Both linear relationships were highly significant (for panel $\mathrm{B}, F_{1,83}=9.8, P=0.0024$; for panel $\mathrm{D}, F_{1,83}=7.2, P=$ $0.009)$. 


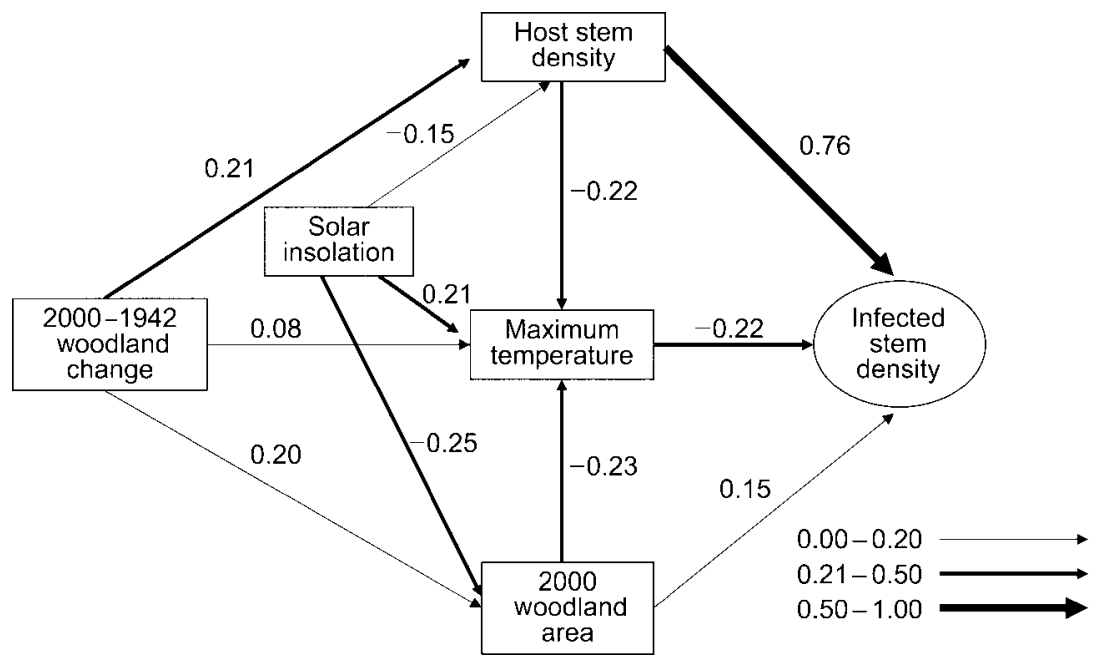

FIG. 6. Path analysis diagram for density of Phytophthora ramorum-infected bay laurel trees, a measure of pathogen inoculum load. The width of the lines illustrates the magnitude of the direct and indirect effects (path coefficients are also shown). Path coefficients for the second measure of inoculum load (symptomatic leaf number) and the disease prevalence measure (proportion of symptomatic stems) are shown in Table 3. See Table 2 for multiple regression results used to construct paths, and Table 3 for decomposition of direct and indirect effects.

and land-cover type in $1942\left(F_{3,83}=2.45 ; P=0.09\right)$, but these relationships were not statistically significant. Moran's I statistic showed that ANCOVA residuals were not spatially autocorrelated. SAR modeling was not used for this analysis due to the inclusion of a categorical variable (Rangel et al. 2006).
The SAR-based path analysis examined how landcover change indirectly affects $P$. ramorum inoculum load and disease prevalence on bay laurel through its direct effects on forest structure, understory microclimate, and woodland area, while accounting for potential spatial autocorrelation (Fig. 6, Table 2). In the resulting

TABLE 2. Regression models used in path analysis of P. ramorum symptom levels on bay laurel.

\begin{tabular}{|c|c|c|c|c|}
\hline $\begin{array}{l}\text { Dependent variable and } \\
\text { independent variables }\end{array}$ & $r^{2}$ & Path coefficient & $t$ & $P$ \\
\hline Woodland area (2000) & 0.10 & & & \\
\hline $\begin{array}{l}\text { Solar insolation index } \\
\text { Change in woodland area (2000-1942) }\end{array}$ & & $\begin{array}{r}-0.25 \\
0.20\end{array}$ & $\begin{array}{r}-2.4 \\
2.0\end{array}$ & $\begin{array}{l}0.017 \\
0.047\end{array}$ \\
\hline Total stem density & 0.08 & & & \\
\hline $\begin{array}{l}\text { Solar insolation index } \\
\text { Change in woodland area (2000-1942) }\end{array}$ & & $\begin{array}{r}-0.15 \\
0.21\end{array}$ & $\begin{array}{r}-1.5 \\
2.3\end{array}$ & $\begin{array}{l}0.139 \\
0.025\end{array}$ \\
\hline $\begin{array}{l}\text { Maximum daily temperature } \\
\text { Solar insolation index } \\
\text { Change in woodland area (2000-1942) } \\
\text { Total stem density } \\
\text { Woodland area (2000) }\end{array}$ & 0.21 & $\begin{array}{r}0.21 \\
0.08 \\
-0.22 \\
-0.23\end{array}$ & $\begin{array}{r}2.2 \\
0.9 \\
-2.2 \\
-2.4\end{array}$ & $\begin{array}{l}0.03 \\
0.395 \\
0.021 \\
0.018\end{array}$ \\
\hline $\begin{array}{l}\text { Number of symptomatic bay laurel stems } \\
\text { Total stem density } \\
\text { Maximum daily temperature } \\
\text { Woodland area (2000) }\end{array}$ & 0.65 & $\begin{array}{r}0.76 \\
-0.22 \\
0.15\end{array}$ & $\begin{array}{r}10.4 \\
-3.2 \\
2.2\end{array}$ & $\begin{array}{c}<0.001 \\
0.002 \\
0.03\end{array}$ \\
\hline $\begin{array}{l}\text { Number of symptomatic bay laurel leaves } \\
\text { Total stem density } \\
\text { Maximum daily temperature } \\
\text { Woodland area (2000) }\end{array}$ & 0.41 & $\begin{array}{r}0.51 \\
-0.22 \\
0.24\end{array}$ & $\begin{array}{r}5.4 \\
-2.5 \\
2.8\end{array}$ & $\begin{array}{r}<0.001 \\
0.015 \\
0.007\end{array}$ \\
\hline $\begin{array}{l}\text { Proportion of bay laurel stems symptomatic } \\
\text { Total stem density } \\
\text { Maximum daily temperature } \\
\text { Woodland area (2000) }\end{array}$ & 0.21 & $\begin{array}{r}0.10 \\
-0.28 \\
0.24\end{array}$ & $\begin{array}{r}0.9 \\
-2.6 \\
2.4\end{array}$ & $\begin{array}{l}0.36 \\
0.001 \\
0.019\end{array}$ \\
\hline
\end{tabular}

Notes: Variables were selected using a criterion approach with AIC as the model-fitting criterion. Variables were transformed when needed to conform to multiple regression assumptions and were standardized before path coefficient calculation. 
TABLE 3. Direct effects, indirect effects, and effect coefficients in path analysis of P. ramorum symptom levels on bay laurel.

\begin{tabular}{|c|c|c|c|}
\hline Dependent and independent variables & Direct effect & Indirect effect & Effect coefficient \\
\hline \multicolumn{4}{|l|}{ Woodland area (2000) } \\
\hline $\begin{array}{l}\text { Solar insolation index } \\
\text { Change in woodland area (2000-1942) }\end{array}$ & $\begin{array}{r}-0.25 \\
0.20\end{array}$ & $\begin{array}{l}0 \\
0\end{array}$ & $\begin{array}{r}-0.25 \\
0.20\end{array}$ \\
\hline \multicolumn{4}{|l|}{ Total stem density } \\
\hline $\begin{array}{l}\text { Solar insolation index } \\
\text { Change in woodland area (2000-1942) }\end{array}$ & $\begin{array}{r}-0.15 \\
0.21\end{array}$ & $\begin{array}{l}0 \\
0\end{array}$ & $\begin{array}{r}-0.15 \\
0.21\end{array}$ \\
\hline $\begin{array}{l}\text { Maximum daily temperature } \\
\text { Solar insolation index } \\
\text { Change in woodland area (2000-1942) } \\
\text { Total stem density } \\
\text { Woodland area (2000) }\end{array}$ & $\begin{array}{r}0.21 \\
0.08 \\
-0.22 \\
-0.23\end{array}$ & $\begin{array}{c}0.09 \\
-0.09 \\
0 \\
0\end{array}$ & $\begin{array}{r}0.30 \\
-0.01 \\
-0.22 \\
-0.23\end{array}$ \\
\hline $\begin{array}{l}\text { Number of symptomatic bay laurel stems } \\
\text { Total stem density } \\
\text { Maximum daily temperature } \\
\text { Woodland area (2000) } \\
\text { Solar insolation index } \\
\text { Change in woodland area (2000-1942) }\end{array}$ & $\begin{array}{l}0.76 \\
-0.22 \\
0.15 \\
0 \\
0\end{array}$ & $\begin{array}{r}0.05 \\
0 \\
0.05 \\
-0.22 \\
0.21\end{array}$ & $\begin{array}{r}0.81 \\
-0.22 \\
0.20 \\
-0.22 \\
0.21\end{array}$ \\
\hline $\begin{array}{l}\text { Number of symptomatic bay laurel leaves } \\
\text { Total stem density } \\
\text { Maximum daily temperature } \\
\text { Woodland area (2000) } \\
\text { Solar insolation index } \\
\text { Change in woodland area (2000-1942) }\end{array}$ & $\begin{array}{r}0.51 \\
-0.22 \\
0.25 \\
0 \\
0\end{array}$ & $\begin{array}{r}-0.11 \\
0 \\
-0.12 \\
-0.20 \\
0.02\end{array}$ & $\begin{array}{r}0.40 \\
-0.22 \\
0.13 \\
-0.20 \\
0.02\end{array}$ \\
\hline $\begin{array}{l}\text { Proportion of bay laurel stems symptoma } \\
\text { Total stem density } \\
\text { Maximum daily temperature } \\
\text { Woodland area (2000) } \\
\text { Solar insolation index } \\
\text { Change in woodland area }(2000-1942)\end{array}$ & $\begin{array}{l}0.10 \\
-0.28 \\
0.24 \\
0 \\
0\end{array}$ & $\begin{array}{l}-0.02 \\
0 \\
-0.02 \\
-0.13 \\
<0.01\end{array}$ & $\begin{array}{r}0.08 \\
-0.28 \\
0.22 \\
-0.13 \\
<0.01\end{array}$ \\
\hline
\end{tabular}

path models, SAR coefficients and $P$ values did not considerably differ from those of ordinary least squares analysis, suggesting minimal spatial dependence in the data set. Other violations of multiple regression were not found, including deviation from variance heterogeneity and nonlinear relationships among transformed variables. The path analysis assumption of independence among error variables was satisfied (Schemske and Horvitz 1988), with very low correlation coefficients $(-0.024$ to 0.0054$)$ among the nine variables $(P>0.8$ for all comparisons).

The analysis revealed that solar insolation was significantly negatively related to woodland area in 2000 , while woodland change was weakly positively related to woodland area in 2000 (Fig. 6, Table 2). Woodland change was significantly positively related to stem density, consistent with the hypothesis that higher density of smaller stems should be associated with younger woodlands. Woodland change and solar insolation were not indirectly affected by other variables because of their position in the path and no correlation among them (Table 3).

Topographic and biotic variables were both significant predictors of maximum temperature in the forest understory (Table 2). Understory maximum temperature was positively related to solar insolation and negatively related to host stem density and the amount of woodland area in 2000 (Table 3, Fig. 6). Also consistent with our hypothesis, number of symptomatic bay leaves was positively related to the density of host stems and woodland area, and negatively related to maximum temperature (Table 2, Fig. 6). Host stem density also had the greatest effect on symptomatic stem density, followed by woodland area and maximum temperature (Table 3). Disease prevalence was also negatively related to maximum temperature and positively related to woodland area, but was not related to total stem density (Table 2). There was an indirect negative effect of solar insolation on all three measures of disease in bay laurel, which is consistent with its positive relationship to maximum temperature. Finally, there was a positive indirect effect of woodland expansion on the three measures of disease status, with the effect being greatest for symptomatic stem density. This is consistent with its positive effects on host stem density and woodland area in 2000 . Thus, the pathogen appears to be most abundant in large, high-density forests that are cooler and less exposed to incoming solar insolation.

\section{Discussion}

The influence of land-cover change on plant-pathogen interactions in nature has rarely been studied (Holdenrieder et al. 2004, Ostfeld et al. 2005), despite 
the recognition of its influence on disease epidemics in humans and agriculture (Foley et al. 2005, Vittor et al. 2006). Our analyses of human impacts on the structure and arrangement of coastal California forests revealed significant links between increases in the density and connectivity of forests and the spread of Phytophthora ramorum, an exotic invasive pathogen responsible for the recent death of potentially millions of oak trees in California and Oregon. Our results strongly suggest that increases in woodland cover have facilitated the establishment of $P$. ramorum by (1) creating larger, more connected woodlands, (2) increasing the density of the key inoculum-producing host bay laurel, and (3) enhancing optimal microclimatic growth conditions for $P$. ramorum in the forest understory.

Our results show a marked decline in spatial heterogeneity of plant communities in our study area over a 58-year period, with considerable loss of grassland and chaparral and increase of forest communities. Chaparral and grassland communities in coastal California are dependent upon recurrent fire disturbance for regeneration or exclusion of woody competitors as well as maintenance of boundaries between land-cover types (Vogl 1974, Keeley 1987, Parsons and Stohlgren 1989, Keeley 2002b). Management policies of fire suppression (of both wildfire and Native American burning) across most of coastal northern California over the last 60 years have likely caused the loss of community heterogeneity documented here. In our study area, fire frequencies changed from every 6.2-23 years before the 20th century to the current status of complete suppression (Finney and Martin 1992, Barnhart et al. 1996).

In our study system, woodland expansion was highly correlated with loss of chaparral communities (Fig. 4). It is possible that the wetter environments of northern California are more marginal for chaparral than dryer chaparral areas to the south, and are therefore more vulnerable to invasion by tree species under altered fire regimes (Keeley 2000, Meentemeyer and Moody 2002). In the absence of fire, Callaway and Davis (1993) also reported a shift of grassland and shrubland communities to oak woodland between 1947 and 1989. Coast live oak trees rarely replaced grassland directly, but invaded chaparral and coastal sage scrub during fire-free periods because shrub cover apparently facilitates survival of oak seedlings (Callaway and D'Antonio 1991, Callaway and Davis 1998, Parikh and Gale 1998). Once beyond the sapling stage, coast live oak is very fire resistant and able to expand into non-forested communities (Callaway and Davis 1993, Sugihara et al. 2006). The key foliar host, bay laurel, may be more common in woodlands not subjected to recurrent fire (Safford 1995) because it is a fast-growing tree and has little protection from fire (Howard 1992). McBride (1974) estimated that, in the absence of fire, plant communities of the East Bay of San Francisco could convert from shrubland to oak woodland to bay laurel-dominated woodland in as little as 50 years. Our study sites also exhibited significantly higher densities of small bay laurel trees compared to coast live oak and black oak, suggesting that woodlands in this region may be experiencing a transition to dominance by bay laurel.

As we hypothesized, path analysis indicated that woodland expansion was associated with a greater density of $P$. ramorum host trees, including coast live oak and bay laurel. Other studies have also shown that these species increase in density with forest canopy closing and woodland expansion (Tunison 1973, Davis et al. 1988, Barnhart 1996, Hunter 1997). Our results suggest that these changes in forest structure facilitated disease in two ways. First, higher density of host trees increased the amount of inoculum produced by each plot, as indicated by the number of symptomatic leaves and the density of infected bay stems (Burdon and Chilvers 1982). This agrees with two recent studies that observed greater levels of $P$. ramorum infection in locations with higher abundance of the foliar host bay laurel (Maloney et al. 2005, Condeso and Meentemeyer 2007). Likewise, Moritz and Odion (2005) suggested that succession toward higher host densities in the absence of fire could cause a relationship between time since fire and P. ramorum presence. Second, we found that higher densities of trees reduce maximum daily understory temperatures. Chen et al. (1999) also showed that greater forest canopy cover limits the amount of incoming solar radiation, effectively lowering maximum understory temperature. Temperature, along with rainfall, can affect the timing and production of inoculum, length of infectious period, host susceptibility, and pathogen dormancy, especially for foliar pathogens (Davidson et al. 2005, Woods et al. 2005). In California's Mediterranean-type climate, $P$. ramorum typically survives through hot, dry summers within symptomatic bay laurel leaves (Davidson et al. 2005). However, summer survival of P. ramorum through dormancy in bay laurel leaves is typically lower in hotter forests with much higher levels of abscission of infected leaves (J. M. Davidson and M. DiLeo, unpublished data). These laboratory and field experiments corroborate our finding that pathogen inoculum load and disease prevalence is greater in forests with cooler maximum temperatures and that high tree density explained considerable variability in the two measures of inoculum load. Though, at this stage of invasion the ANCOVA and path analysis models explained considerably more variability in the two measures of inoculum load than disease prevalence in bay laurel.

Woodland expansion also appears to be increasing landscape-level connectivity of host vegetation for $P$. ramorum. During the 58-year study period, the size of woodland patches increased $50 \%$, leading to a significantly smaller number of woodland areas surrounded by non-host vegetation that may inhibit wind-blown dispersal of the pathogen (Rizzo et al. 2005). As hypothesized, our path analysis indicated a positive 


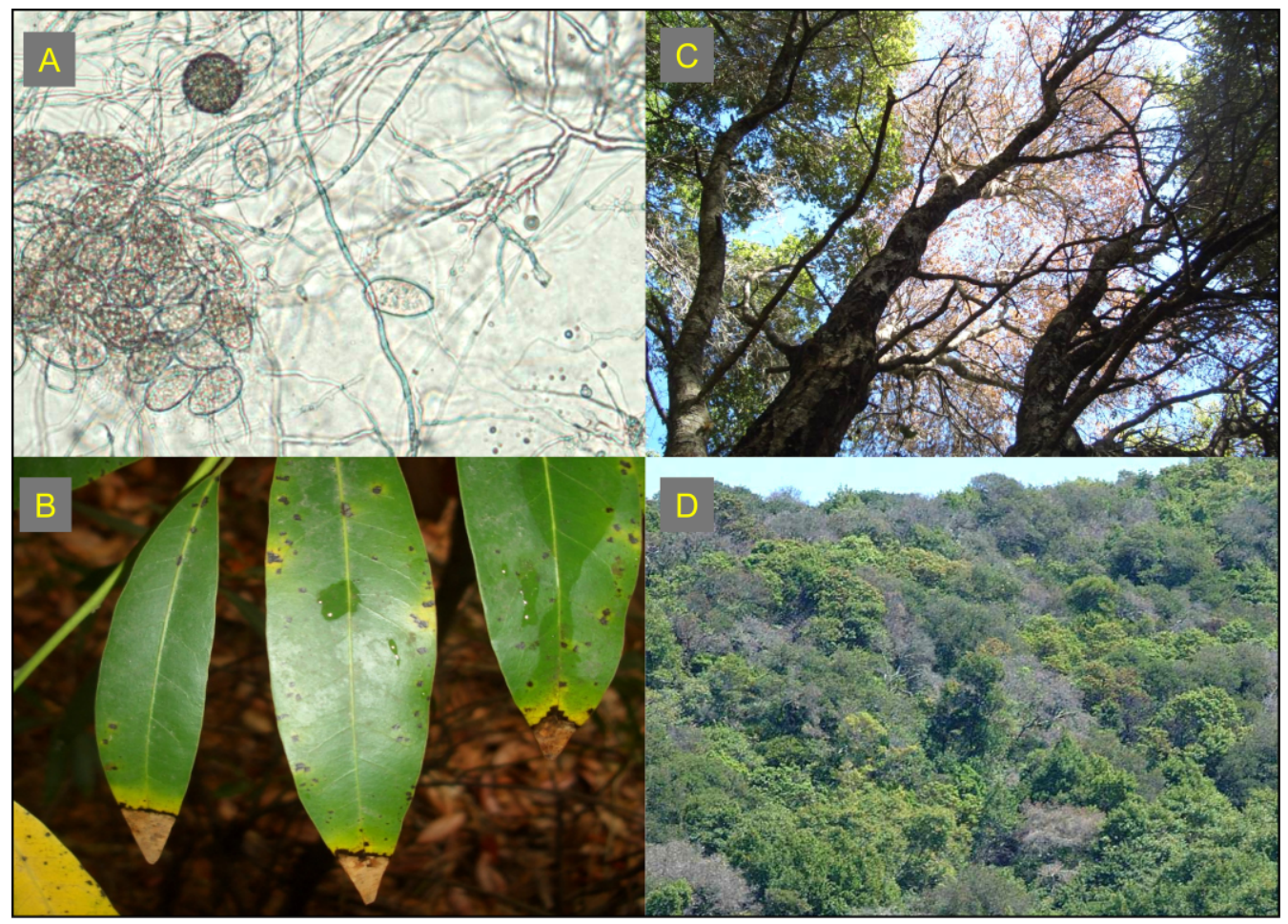

Plate 1. Phytophthora ramorum and the diseases it causes. (A) Microscopic view of P. ramorum showing mycelium, sporangia (asexual reproductive structure), and a chlamydospore (dormant propagule). (B) Symptoms of P. ramorum infection on bay laurel (Umbellularia californica) leaves; necrotic leaf tips on bay laurel are the primary site of pathogen sporulation as shown in panel (A). (C) Coast live oak (Quercus agrifolia) mortality caused by P. ramorum. (D) P. ramorum-caused oak mortality surrounded by individuals of the infectious host bay laurel in a typical California mixed evergreen woodland. Photo credits: (A) N. Rank, (B) K. Aram, (C) and (D), D. Rizzo.

relationship between pathogen inoculum load as well as disease prevalence and the amount of woodland area surrounding a plot. This result is consistent with the findings of Condeso and Meentemeyer (2007) that landscape heterogeneity of host vegetation influences pathogen inoculum load. The relationship between woodland area and disease is also consistent with other epidemiological studies of interactions between the size of host populations and rates of infection (Burdon et al. 1995, Thrall et al. 2003). Large areas of host vegetation may also increase colonization rates by providing larger areas for interception of wind-blown spores than smaller ones (Burdon 1987, Condeso and Meentemeyer 2007). Once infected, larger patches of woodland may also support larger $P$. ramorum populations, increasing the probability of local population persistence during unfavorable environmental conditions (Burdon 1987). Finally, larger woodlands contain more interior areas that are buffered against temperature and moisture extremes typical of smaller patches with higher proportions of edge habitat (Chen et al. 1999).

Our results showing that land-use changes have enhanced habitat conditions for P. ramorum establishment suggest several possible management implications for controlling further disease spread. Management strategies that should be explored include reintroduction of low-intensity prescribed fire and thinning of bay laurel in infected and susceptible sites. Periodic prescribed fires may effectively limit dominance by bay laurel (Rizzo et al. 2005) and prevent further expansion of woodland edges into adjacent grassland and chaparral communities (McBride 1974, Callaway and Davis 1993, Safford 1995). If implemented effectively, reducing the abundance of host vegetation through fire management could also restore canopy gaps, which may in turn reduce favorable microclimate conditions for the pathogen by increasing solar radiation in forest understories (Condeso and Meentemeyer 2007). However, there currently is little evidence that introduction of fire to heavily infected forests can completely eradicate $P$. ramorum either through increased heat or smoke. Eradication efforts in Oregon, for example, have included broadcast burns that have not eliminated the pathogen (Rizzo et al. 2005). In addition, surprisingly little is known about historical fire regimes in coastal mixed-evergreen forests and how prescribed fire would fit into natural patterns of forest succession (Davis and Borchert 2006, Stuart and Stephens 2006). Finally, prescribed burns are costly to implement and pose substantial risk in areas with human development. Thus, mechanical thinning of bay laurel vegetation may be an even more effective way of reducing inoculum pressure 
in forest understories (Rizzo et al. 2005). Ultimately, more research is needed to understand the efficacy of possible management solutions that can be applied at landscape to regional scales and the potential for unintended ecological consequences of prescribed fire or vegetation thinning in woodland ecosystems (Moritz and Odion 2005, Rizzo et al. 2005). Prior to application of such management activities at broad spatial scales, small-scale manipulative experiments are needed to reveal which types of treatments may be most effective at limiting disease transmission and persistence.

By the mid 1990s, when Phytophthora ramorum was first observed in California, decades of land-use and land-cover changes likely resulted in forest conditions that promoted establishment and spread of this pathogen. Without management intervention, we expect increases in foliar-host vegetation to continue and promote further spread of infection onto neighboring bay laurel and oak trees. This study emphasizes the importance of incorporating land-cover change into plant epidemiology studies for understanding disease dynamics, informing land management activities, and preventing the intensification and spread of this destructive pathogen. It should also focus our attention on the strong and persistent impacts of human land-use history on natural ecosystems.

\section{ACKNOWLEDGMENTS}

We thank J. Amaris, S. Benson, C. Boylen, T. E. Condeso, M. Cooper, D. Dann, G. Garner, A. Gauthier, E. Gordon, R. Hunter, S. King, M. Kozanitas, N. MacCallum, E. McCowan, L. Miller, S. Moyle, G. Neargarder, H. Torpin, K. Ward, and J. Zanzot for assistance with field work; D. Young and K. Ward for mapping assistance; and D. DiPietro and E. Lotz for logistical support. This research was supported by grants from the National Science Foundation (DBI-0217064), USDA Forest Service (Pacific Southwest Research Station), the CSU Agricultural Research Initiative, the Gordon and Betty Moore Foundation, and the Sonoma County Fish and Wildlife Advisory Board.

\section{Literature Cited}

Allan, B. F., F. Keesing, and R. S. Ostfeld. 2003. Effect of forest fragmentation on lyme disease risk. Conservation Biology 17:267-272.

Barbour, M., B. Pavlik, F. Drysdale, and S. Lindstrom. 1993. California's changing landscapes. Diversity and conservation of California vegetation. California Native Plant Society, Sacramento, California, USA.

Barnhart, S. J., J. R. McBride, and P. Warner. 1996. Invasion of northern oak woodlands by Pseudotsuga menziesii (mirb.) Franco in the Sonoma Mountains of California. Madroño 43:28-45.

Burdon, J. J. 1987. Diseases and plant population biology. Cambridge University Press, New York, New York, USA.

Burdon, J. J., and G. A. Chilvers. 1982. Host density as a factor in plant disease ecology. Annual Review of Phytopathology 20:143-166.

Burdon, J. J., L. Ericson, and W. J. Müller. 1995. Temporal and spatial changes in a metapopulation of the rust pathogen Triphragmium ulmariae and its host, Filipendula ulmaria. Journal of Ecology 83:979-989.

Callaway, R. M., and C. D'Antonio. 1991. Shrub facilitation of coast live oak establishment in central California chaparral. Madroño 38:158-169.
Callaway, R. M., and F. W. Davis. 1993. Vegetation dynamics, fire, and the physical environment in central California. Ecology 74:1567-1578.

Callaway, R. M., and F. W. Davis. 1998. Recruitment of Quercus agrifolia in central California: The importance of shrub-dominated patches. Journal of Vegetation Science 9: 647-656.

Chen, J., S. C. Saunders, T. R. Crow, R. J. Naiman, K. D. Brosofske, G. D. Mroz, B. L. Brookshire, and J. F. Franklin. 1999. Microclimate in forest ecosystem and landscape ecology: Variations in local climate can be used to monitor and compare the effects of different management regimes. BioScience 49:288-297.

Coluzzi, M. 1994. Malaria and the Afrotropical ecosystems: impact of man-made environmental changes. Parassitologia 36:223-227.

Condeso, T. E., and R. K. Meentemeyer. 2007. Effects of landscape heterogeneity on the emerging forest disease Sudden Oak Death. Journal of Ecology 95:364-375.

Cressie, N. A. C. 1993. Statistics for spatial data. Wiley, Hoboken, New Jersey, USA.

Davidson, J. M., D. M. Rizzo, M. Garbelotto, S. Tjosvold, and G. W. Slaughter. 2002. Phytophthora ramorum and sudden oak death in California: II. Pathogen transmission and survival. Pages 741-749 in R. Standiford and D. McCreary, editors. Proceedings of the fifth symposium on oak woodlands: oaks in California's changing landscape. General Technical Report PSW-GTR-184. U.S. Department of Agriculture, Forest Service, Albany, Pacific Southwest Research Station, California, USA.

Davidson, J. M., S. Werres, M. Garbelotto, E. M. Hansen, and D. M. Rizzo. 2003. Sudden oak death and associated diseases caused by Phytophthora ramorum. Plant Health Progress [doi: 10.1094/PHP-2003-0707-01-DG].

Davidson, J. M., A. Wickland, H. A. Patterson, K. R. Falk, and D. M. Rizzo. 2005. Transmission of Phytophthora ramorum in mixed-evergreen forest in California. Phytopathology 95:587-596.

Davis, F. W., and M. I. Borchert. 2006. Central coast bioregion. Pages 321-349 in N. G. Sugihara, J. W. Van Wagtendonk, K. E. Shaffer, J. Fites-Kaufman, and A. E. Thode, editors. Fire in California's ecosystems. University of California Press, Berkeley, California, USA.

Davis, F. W., D. E. Hickson, and D. C. Odion. 1988. Composition of maritime chaparral related to fire history and soil, Burton Mesa, Santa Barbara County, California. Madroño 35:169-195.

Diniz-Filho, J. A., L. M. Bini, and B. A. Hawkins. 2003. Spatial autocorrelation and red herrings in geographical ecology. Global Ecology and Biogeography 12:53-64.

Dubayah, R. C. 1994. Modeling a solar-radiation topoclimatology for the Rio-Grande river basin. Journal of Vegetation Science 5:627-640.

Dupouey, J. L., E. Dambrine, J. D. Laffite, and C. Moares. 2002. Irreversible impact of past land use on forest soils and biodiversity. Ecology 83:2978-2984.

Finney, M. A., and R. E. Martin. 1992. Short-fire intervals recorded by redwoods at Annadel State Park. Madroño 22: 231-238.

Foley, J. A., et al. 2005. Global consequences of land use. Science 309:570-574.

Foster, D., F. Swanson, J. Aber, I. Burke, N. Brokaw, D. Tilman, and A. Knapp. 2003. The importance of land-use legacies to ecology and conservation. BioScience 53:77-88.

Garbelotto, M., D. M. Rizzo, J. M. Davidson, K. Ivors, P. E. Maloney, D. Hüberli, D. Hayden, T. Harnik, and S. T. Koike. 2003. Phytophthora ramorum: an emerging forest pathogen. Phytopathology 93:S28.

Grace, J. B., and B. H. Pugesek. 1998. On the use of path analysis and related procedures for the investigation of ecological problems. American Naturalist 152:151-159.

Holdenrieder, O., M. Pautasso, P. J. Weisberg, and D. Lonsdale. 2004. Tree diseases and landscape processes: the 
challenge of landscape pathology. Trends in Ecology and Evolution 19:446-452.

Howard, J. L. 1992. Umbellularia californica. In Fire effects information system. U.S. Department of Agriculture, Forest Service, Rocky Mountain Research Station, Fire Sciences Laboratory. 〈http://www.fs.fed.us/database/feis/plants/tree/ umbcal/introductory.html $\rangle$

Hunter, J. C. 1997. Fourteen years of change in two old-growth Pseudotsuga-Lithocarpus forests in northern California. Journal of the Torrey Botanical Society 124:273-279.

Keeley, J. E. 1987. Role of fire in the seed germination of woody taxa in California chaparral. Ecology 68:434-443.

Keeley, J. E. 2000. Chaparral. Pages 201-253 in M. G. Barbour and W. D. Billings, editors. North American terrestrial vegetation. Second edition. Cambridge University Press, Cambridge, UK.

Keeley, J. E. 2002a. Native American impacts on fire regimes of the California coastal ranges. Journal of Biogeography 29: 303-320.

Keeley, J. E. 2002b. Fire management of California shrubland landscapes. Environmental Management 29:395-408.

Kelly, N. M., and R. K. Meentemeyer. 2002. Landscape dynamics of the spread of sudden oak death. Photogrammetric Engineering and Remote Sensing 68:1001-1009.

Legendre, P. M., R. R. Dale, M. J. Fortin, J. Gurevitch, M. Hohn, and D. Myers. 2002. The consequences of spatial structure for the design and analysis of field surveys. Ecography 25:601-615.

Lichstein, J. W., T. R. Simons, S. A. Shriner, and K. E. Franzreb. 2002. Spatial autocorrelation and autoregressive models in ecology. Ecological Monographs 72:445-463.

Maloney, P. E., S. C. Lynch, S. F. Kane, C. E. Jensen, and D. M. Rizzo. 2005. Establishment of an emerging generalist pathogen in redwood forest communities. Journal of Ecology 93:899-905.

McBride, J. R. 1974. Plant succession in the Berkeley Hills, California. Madroño 22:317-329.

McGarigal, K., S. A. Cushman, M. C. Neel, and E. Ene. 2002. FRAGSTATS: spatial pattern analysis program for categorical maps. University of Massachusetts, Amherst, Massachusetts, USA.

Meentemeyer, R. K., and A. Moody. 2002. Distribution of plant life history types in California chaparral: the role topographically-determined drought severity. Journal of Vegetation Science 13:67-78.

Meentemeyer, R. K., D. M. Rizzo, W. Mark, and E. Lotz. 2004. Mapping the risk of establishment and spread of Sudden Oak Death in California. Forest Ecology and Management 200:195-214.

Merenlender, A. M. 2000. Mapping vineyard expansion provides information on agriculture and the environment. California Agriculture 54:7-12.

Moore, I. D., R. B. Grayson, and A. R. Ladson. 1991. Digital terrain modeling: a review of hydrological, geomorphological, and biological applications. Hydrological Processes 5:330 .

Moritz, M. A., and D. C. Odion. 2005. Examining the strength and possible causes of the relationship between fire history and Sudden Oak Death. Oecologia 144:106-114.

Ostfeld, R. S., G. Glass, and F. Keesing. 2005. Spatial epidemiology: an emerging (or re-emerging) discipline. Trends in Ecology and Evolution 20:328-336.

Parikh, A., and N. Gale. 1998. Coast live oak revegetation on the central coast of California. Madroño 45:301-309.

Parsons, D. J., and T. Stohlgren. 1989. Effects of varying fire regimes on annual grasslands in the southern Sierra Nevada of California. Madroño 36:154-168.

Patz, J. A., T. K. Graczyk, N. Geller, and A. Y. Vittor. 2000. Effects of environmental change on emerging parasitic diseases. International Journal for Parasitology 30:13951405.

Rangel, T. F. L. V. B., J. A. F. Diniz-Filho, and L. M. Bini. 2006. Towards an integrated computational tool for spatial analysis in macroecology and biogeography. Global Ecology and Biogeography 15:321-327.

Rice, W. R. 1989. Analyzing tables of statistical tests. Evolution 43:223-225.

Rizzo, D. M., and M. Garbelotto. 2003. Sudden oak death: endangering California and Oregon forest ecosystems. Frontiers in Ecology and the Environment 1:197-204.

Rizzo, D. M., M. Garbelotto, J. M. Davidson, G. W. Slaughter, and S. T. Koike. 2002. Phytophthora ramorum as the cause of extensive mortality of Quercus spp. and Lithocarpus densiflorus in California. Plant Disease 86:205-214.

Rizzo, D. M., M. Garbelotto, and E. M. Hansen. 2005. Phytophthora ramorum: integrative research and management of an emerging pathogen in California and Oregon forests. Annual Review of Phytopathology 43:309-335.

Safford, H. D. 1995. Woody vegetation and succession in the Garin Woods, Hayward Hills, Alameda County, California. Madroño 42:470-489.

Schemske, D. W., and C. C. Horvitz. 1988. Plant-animal interactions and fruit production in a neotropical herb: a path analysis. Ecology 69:1128-1137.

Shipley, B. 1997. Exploratory path analysis with applications in ecology and evolution. American Naturalist 149:1113-1138.

Stuart, J. D., and S. L. Stephens. 2006. North coast bioregion. Pages 147-169 in N. G. Sugihara, J. W. Van Wagtendonk, K. E. Shaffer, J. Fites-Kaufman, and A. E. Thode, editors. Fire in California's ecosystems. University of California Press, Berkeley, California, USA.

Sugihara, N. G., J. W. Van Wagtendonk, K. E. Shaffer, J. Fites-Kaufman, and A. E. Thode, editors. 2006. Fire in California's ecosystems. University of California Press, Berkeley, California, USA.

Swiecki, T. J., and E. Bernhardt. 2006. Disease risk factors and disease progression in coast live oak and tanoak affected by Phytophthora ramorum canker (sudden oak death). Proceedings of the second Sudden Oak Death Science Symposium. January 18-21, 2005; Monterey, California. General Technical Report PSW-GTR-196. U.S. Department of Agriculture, Forest Service, Pacific Southwest Research Station, Albany, California, USA.

Thrall, P., R. Godfree, and J. J. Burdon. 2003. Influence of spatial structure on pathogen colonization and extinction: a test using an experimental metapopulation. Plant Pathology $52: 350-361$.

Tunison, J. T. 1973. A synecological study of the oakdominated communities of Bennett Mountain, Sonoma County, California. Thesis. Sonoma State University, Rohnert Park, California, USA.

Turner, M. G., S. R. Carpenter, E. J. Gustafson, R. J. Naiman, and S. M. Pearson. 1998. Land use. Pages 37-61 in M. J. Mac, P. A. Opler, P. Doran, and C. Haecker, Status and trends of our nation's biological resources. Volume 1. USGS National Biological Service, Washington, D.C., USA.

Turner, M. G., S. M. Pearson, P. Bolstad, and D. N. Wear. 2003. Effects of land-cover change on spatial pattern of forest communities in the Southern Appalachian Mountains (USA). Landscape Ecology 18:449-464.

Vittor, A. Y., R. H. Gilman, J. Tielsch, G. Glass, T. Shields, W. S. Lozano, V. Pinedo-Cancino, and J. A. Patz. 2006. The effect of deforestation on the human-biting rate of Anopheles darlingi, the primary vector of falciparum malaria in the Peruvian Amazon. American Journal of Tropical Medicine and Hygiene 74:3-11.

Vogl, R. J. 1974. Effects of fire on grasslands. Pages 139-194 in T. T. Kozlowski and C. E. Ahlgren, editors. Fire and ecosystems. Academic, New York, New York, USA.

Wear, D. N., M. G. Turner, and R. J. Naiman. 1998. Land cover along an urban-rural gradient: implications for water quality. Ecological Applications 8:619-630.

Woods, A., K. D. Coates, and A. Hamann. 2005. Is an unprecedented Dothistroma needle blight epidemic related to climate change? BioScience 55:761-769. 